\title{
Prečo l'udia volia populistickú radikálnu pravicu? Geografická analýza volebnej podpory populistickej radikálnej pravice v Česku a na Slovensku ${ }^{1}$
}

\author{
Dominik Kevický ${ }^{2}$ \\ Geografický ústav, Př́rodovědecká fakulta, Masarykova univerzita, Brno

\begin{abstract}
Why do People Vote for a Populist Radical Right? Geographical Analysis of Populist Radical Right Support in Czechia and Slovakia. Nowadays, the electoral success of the populist radical right is increasing across Europe. The objective of the study is to identify social factors which can potentially explain the geographical variability of the populist radical right in Czechia and Slovakia. The empirical analysis was based on multiple regression analysis. The results have shown that populist radical right parties in Czechia have larger support in districts with a lower voter turnout in the elections to the European parliament. And the share of the population with Slovak nationality is the most crucial factor for populist radical parties in Slovakia.

Sociológia 2021, Vol. 53 (No. 6: 577-598)

https://doi.org/10.31577/sociologia.2021.53.6.22
\end{abstract}

Key words: Populist radical right; theory of cleavages; grievance theory; regression analysis; Czechia; Slovakia

\section{Úvod}

V poslednom desat'ročí sa v Európe zväčšuje volebný úspech populistickej radikálnej pravice. Medzi jej úspechy sa spomína postúpenie Marine Le Pen do druhého kola prezidentských volieb vo Francúzsku, tretie miesto pre Alternatívu pre Nemecko v nemeckých vol'bách do Bundestagu alebo druhé miesto pre holandskú Stranu slobody v parlamentných vol'bách. Všetky tieto úspechy sa uskutočnili v rámci roku 2017.

Populistická radikálna pravica zaznamenáva úspech taktiež na Slovensku a v Česku, kde je v posledných desiatich rokoch pozorovatel'ný nárast jej volebnej podpory a varlamentných vol'bách dokázali byt' úspešné i nové populisticko-radikálne pravicové strany (Kotlebovci - Ludová strana Naše Slovensko, Svoboda a př́má demokracie). Ponúkajú sa otázky, prečo l’udia v Česku a na Slovensku volia populistickú radikálnu pravicu? Aké sú faktory ovplyvňujú rozloženie volebnej podpory populisticko-radikálnych pravicových strán? Dajú sa k vysvetleniu rozloženia volebnej podpory populistickej radikálnej pravice v Česku a na Slovensku použit' existujúce teoretické koncepty? Tieto položené otázky sa pokúsi zodpovedat' tento príspevok.

\footnotetext{
1 Príspevok vznikol v rámci projektu špecifického výskumu MUNI/A/1570/2020 Geografický výzkum dynamiky přírodních a společenských prostorových procesů.

Korešpondencia: RNDr. Dominik Kevický, Geografický ústav, Př́rodovědecká fakulta, Masarykova univerzita, Kotlářská 267/2, 61137 Brno, Česká republika. E-mail: kevicky.dominik@mail.muni.cz
} 
Článok sa najskôr zameria na vývoj populistickej radikálnej pravice v Európe a na predstavenie teoretických prístupov, ktoré ponúkajú možné odpovede na vyššie spomenuté otázky. Ďalej sú vysvetlené metodické postupy práce a predstavené výsledky uskutočnených analýz zakončené diskusiou nad získanými výsledkami.

\section{Vývoj a výskum populistickej radikálnej pravice}

Od konca druhej svetovej vojny politológovia zaznamenali celkovo tri vlny šírenia podpory populisticko-radikálnych pravicových strán v západnej Európe (Mudde 1996). Za prvú vlnu sa považuje nástup neofašistických a neonacistických strán v Nemecku a Taliansku krátko po vojne. Za druhú vlnu označujú šírenie v 50. až 70. rokoch 20. storočia vo Francúzsku a škandinávskych štátoch, ktoré takto protestovali proti vysokým daniam. Tretia vlna šírenia krajnej pravice nastáva $\mathrm{v} 80$. rokoch nástupom radikálnych a výrazne xenofóbnych strán (Mudde 1996). Od predchádzajúcich vín sa však strany populistickej radikálnej pravice $\mathrm{v}$ tretej vlne odlišujú. Preto viacerí autori rozdelujú populisticko-radikálne pravicové strany na tzv. „starú a novú radikálnu pravicu“ (Mikuš - Gurňák 2019).

Podl'a Rydgrena (2007) je nová populistická radikálna pravica menej agresívna a viac než o celosvetovú neofašistickú a neonacistickú rasovú čistotu sa snaží o etnickú čistotu v rámci štátu. Tieto strany teda uznávajú aj ostatné etniká, ale iba $\mathrm{v}$ rámci ich vlastných národných hraníc. Nová populistická radikálna pravica sa tiež viacej pozerá na odkazy z minulosti.

Popularita populistickej radikálnej pravice začína narastat' medzi rokmi 2007 a 2009 počas ekonomickej krízy. K nárastu popularity tiež napomohlo riešenie migračnej krízy v rokoch 2015 a 2016, nespokojnost' s fungovaním Európskej únie (Vasilopoulou 2018) a nárast islamofóbie (Kallis 2018) súvisiaci s teroristickými útokmi v Európe. Mikuš a Gurňák (2019) označujú toto obdobie ako začiatok štvrtej vlny šírenia populistickej radikálnej pravice, ktoré sa síce podobá charakteristikou populisticko-radikálnych pravicových strán predchádzajúcemu obdobiu, ale navyše sa zvyšuje podpora kvôli nedôvere voličov v hlavné politické strany a hl'adaniu iných alternatív.

Bornschier (2018) poukazuje na to, že k rozvoju populistickej radikálnej pravice napomáhajú tiež globálne procesy. Jedná sa napríklad o globalizáciu obchodu a trhu alebo vplyv nadnárodných spoločnosti na fungovanie ekonomiky štátu. Tieto procesy z ekonomického hladiska spôsobujú narúšanie tradičných konfliktných línii a tým sa tiež stierajú politické rozdiely medzi mainstreamovými l'avicovými a pravicovými politickými stranami. Toto stieranie rozdielov spôsobuje, že populisticko-radikálne pravicové strany môžu viac vyniknút' svojím programom, ktorý často býva namierený proti súčasnej globalizácii obchodu a zameriava sa na ochranu tuzemskej ekonomiky a 
výrobcov. Oslabovanie ekonomickej problematiky v politickom súboji tiež spôsobuje výraznejšie vyzdvihovanie kultúrnych problémov, s ktorými často pracujú v svojich programoch práve populisticko-radikálne pravicové strany.

Essletzbichler, Disslbacher a Moser (2018) skúmajú vzt’ah neoliberálnej globalizácie a podpory populisticko-radikálnych politických subjektov. Záverom je, že populistická radikálna pravica je úspešná v regiónoch $\mathrm{s}$ nízkym, ale narastajúcim podielom migrantov, $\mathrm{v}$ starých industriálnych regiónoch, v oblastiach s výrazne zasiahnutým trhom práce ekonomickou krízou s horším procesom zotavenia a v regiónoch s vyššou nezamestnanost'ou. Voličom populisticko-radikálnych strán v týchto oblastiach prekážajú ekonomické (ako napríklad deindustralizácia, vol’ný globálny trh) i kultúrne (akceptácia multikultúrneho životného štýlu, migrantov alebo LGBT komunity) aspekty globalizácie.

$\mathrm{Na}$ rozdiel od oblasti západnej Európy, kde sa populistickej radikálnej pravici venujú autori už od 80 . rokoch 20 . storočia, nastáva záujem o populistickú radikálnu pravicu vo východnej a strednej Európe až na prelome 20. a 21. storočia. K prvým prácam venujúcim sa tejto problematike patrí článok Mudda (2000). Ten rozdeluje populisticko-radikálne pravicové strany do troch kategórií, podla ich historického zasadenia. Prvou kategóriou sú strany, ktoré majú historické základy ešte pred nástupom komunistického režimu, ako je napríklad Slovenská národná strana. Druhou kategóriou sú pravicové strany vznikajúce v období komunizmu. Do tejto kategórie Mudde zarad’uje rumunské strany Partidul Unității Națiunii Române a Partidul România Mare. Do tretej kategórie zarad'uje politické strany, ktoré vznikajú až po páde komunistického režimu, ako je napríklad české Sdružení pro republiku - Republikánská strana Československa.

Vo svojej neskoršej práci Mudde (2005) označuje populistickú radikálnu pravicu vo východnej a strednej Európe za rasistickú a extrémistickú. Podla neho sú dôležitými aspektami pre pochopenie populistickej radikálnej pravice štúdium subkultúr a otázky minorít v daných štátoch. Podl’a Minkenberga (2002) štúdium populistickej radikálnej pravice v 90. rokoch 20. storočia v transformujúcich sa štátoch strednej a východnej Európy pripomína strel'bu na pohyblivý terč a popritom aj strel'bu so zhoršením videním. Toto tvrdenie zdôvodňuje špecifickým historickým a politickým vývojom, ktorý zahrňuje obdobie totalitných režimov, nedokončenú transformáciu a vývoj politického systému. Preto Minkenberg tvrdí, že použitie výskumných metód používaných pri štúdiu populistickej radikálnej pravice $\mathrm{v}$ západnej Európe, nie je vhodné na štúdium tejto politickej rodiny v 90 . rokoch 20 . storočia v strednej a východnej Európe.

Podl'a Bustikovej (2018) sa populistická radikálna pravica vo východnej Európe vyznačuje tromi špecifikami oproti populistickej radikálnej pravici 
v západnej Európe. Prvé je, že v rámci ekonomického hl’adiska majú strany populistickej radikálnej pravice viac názory charakteristické pre laavicové strany, než pre strany pravicové. Druhé špecifikum je, že spájajú proces demokratizácie s udel’ovaním práv pre menšiny a s ich zvýhodňovaním nad majoritnou spoločnost'ou. Tretie špecifikum je, že dochádza $\mathrm{k}$ radikalizácii mainstreamových politických strán, ktoré potom koexistujú so stranami populistickej radikálnej pravice.

Postupne sa problematike populistickej radikálnej pravice $\mathrm{v}$ strednej a východnej Európe venujú aj autori zo skúmaných krajín. Tí sa venujú analýze populistickej radikálnej pravice na území jedného štátu (Mareš 2003; Sum 2010; Mikuš - Gurňák 2012; Gregor 2015; Kasprowicz 2015; Krekó - Mayer 2015; Kluknavská - Smolík 2016; Mikešová 2019) alebo analyzujú populistickú radikálnu pravicu vo viacerých štátoch (Kupka et al. 2009; Mikuš Gurňák 2016, 2019). Ich výskumy poukazujú na to, že populistické radikálne strany sa zo začiatku výrazne akcentovali na rómsku problematiku a zlú ekonomickú situáciu vo vybraných regiónoch. V posledných rokoch sa však do popredia dostáva migračná kríza, strach z islamu, ochrana krest’anských hodnôt alebo euroskepticizmus, čím sa začínajú viac približovat' stranám populistickej radikálnej pravice v západnej Európe (Polyakova 2015; Pytlas 2018).

Aké kritéria však musí strana splńnat, aby mohla byt' označená za populisticko-radikálne pravicovú? Podl’a Mudda (2007) to sú nativizmus, autoritárstvo a populizmus. Nativizmus je kombináciou nacionalizmu a xenofóbie. Preto sa nativistické politické strany vyznačujú na jednej strane protiimigrantskými postojmi, xenofóbiou k národnostným, náboženským alebo iným menšinám a upozorňovaním na vonkajšie ohrozenie štátu, na druhej strane vyzdvihovaním vlastného národa a presadzovaním ekonomického protekcionizmu.

Druhým kritériom sú znaky autoritárstva. Mudde (2007) nepovažuje za znak autoritárstva nutne iba protidemokratické postoje strán, ale ako autoritárstvo berie i vieru v prísne usporiadanej spoločnosti, v ktorej sa prísne trestajú porušenia tohto usporiadania. Čiže strany akcentujú témy kriminality, prísnych trestov pre zločincov a zavedenie poriadku $\mathrm{v}$ štáte.

Tretím kritériom je populizmus. Podl'a Mudda (2007) sa populistické strany vyznačujú delením spoločnosti na l’ud a skorumpovanú elitu a výrazne podporujú vôl'u l'udu napríklad snahou presadit' referendá. Populistické strany tiež glorifikujú l’ud ako zdroj mravnosti a cnosti, pričom táto glorifikácia výrazne kontrastuje s kritikou elity (Stanley 2011).

\section{Teoretické koncepty}

K tradičným teóriám, pomocou ktorých sa vysvetluje podpora politických strán, je teória konfliktných línií (anglicky cleavages). Lipset a Rokkan (1967) vytvorili tuto teórii za účelom popisu vzniku politických strán v západnej 
Európe v 19. storočí. Autori hovoria, že najprv vznikajú konfliktné línie rozdel'ujúcu spoločnost' do niekol'kých skupín, pre ktoré vznikajú politické strany akcentujúce požiadavky danej skupiny.

Historickými kontextmi výrazne ovplyvňujúcimi spoločnost' a vedúcimi $\mathrm{k}$ štepeniu spoločnosti boli národná a industriálna revolúcia. Národná revolúcia spôsobila vznik dvoch konfliktných línií. Rozpor medzi štátom a cirkvou súvisel so sekularizáciou, ktorú preferovali zástancovia moderných národných vlád. Na druhej strane boli zástancovia tradičného ponímania štátu s podporou cirkvi. Dôležitú úlohu v tejto konfliktnej línii zohrával spor o kontrolu vzdelávania. Druhá konfliktná línia sporu centra a periférií vychádzala z toho, že $\mathrm{s}$ vznikom centrálnych vlád vznikali aj protipólne subjekty na perifériách, ktoré nesúhlasili s politikou centra. Periférne subjekty mohli získavat' podporu od politických centier z iných štátov.

Zatial' čo konfliktné línie vzniknuté dôsledkom tvorby moderných národných vlád mali svoj základ v kultúrnych a náboženských aspektoch, tak konfliktné línie vzniknuté dôsledkom industriálnej revolúcie mali primárne ekonomický aspekt. Prvou takou konfliktnou líniou bol konflikt medzi mestom a vidiekom. V 19. storočí sa táto konfliktná línia dala chápat' aj v kontexte súboja medzi vlastníkmi pôd a majitel'mi továrni a obchodníkmi, čiže ako sektorový konflikt primárneho sektoru ekonomiky so sekundárnym. Avšak klesajúca dominancia primárneho sektoru ekonomiky na vidieku v súčasnosti oslabuje sektorový pohl'ad na túto konfliktnú líniu. Druhá konfliktná línia sú robotníci verzus zamestnávatelia, ktorá býva označovaná aj ako súboj medzi pravicou a l'avicou a vedie k vzniku základnej osi politických strán. Lavicové socialistické a sociálnodemokratické strany vo väčšej miere podporujú záujmy robotníkov, zatial' čo na strany zamestnávatel'ov, obchodníkov a živnostníkov sa viac stávajú občianske pravicové strany (Hloušek - Kopeček 2004).

Pôvodná teória konfliktných línií popisovala systém vzniku politických strán v 19. storočí, a preto sa musela prispôsobit' politickým i sociálnym zmenám v druhej polovici 20. storočia. Zmeny primárne súviseli so zmenou hodnotových postojov obyvatel’ov západnej Európy, pričom dôležitú úlohu zohrával nárast kvality života a nárast vysokoškolsky vzdelaných obyvatel'ov. Tieto zmeny viedli $\mathrm{k}$ tomu, že sa začali dostavat' do popredia viac postmaterialistické hodnoty a postoje pri rozhodovaní voličov o výbere politickej strany (Hloušek - Kopeček 2004). Tento proces viedol k vzniku nových politických skupín ako sú napríklad nová l'avica, strany zelených alebo nová pravica, pre ktoré tradičná teória konfliktných línií nebola úplne použitel’ná. Vznik nových politických skupín viedol aj k ich súboju so „starými“" stranami, ktorý vytváral novú konfliktnú líniu materializmus verzus postmaterializmus (Hloušek - Kopeček 2004). 
Vzhl'adom k týmto zmenám sa autori snažili upravit' teóriu konfliktných línií. Lijphart (1999) k tradičným štyrom konfliktným líniám pridal d’alšie tri, aj ked' sám namiesto pojmu konfliktné línie používal pomenovanie ideologické dimenzie. Prvou novou konfliktnou líniou je podpora režimu. Jedna sa o konflikt medzi stranami, ktoré podporujú stávajúci politický režim a stranami, ktoré naopak požadujú výraznú zmenu režimu. Ako typický príklad protirežimných strán Lijphart považoval západoeurópske komunistické strany, avšak v súčasnosti by sa takto dali označit' i niektoré populisticko-radikálne pravicové strany. Druhou konfliktnou líniou je zahranično-politická dimenzia, ktorá súvisí hlavne s otázkou európskej integrácie, kde sa politické strany delia na eurooptimistické a euroskeptické. Tret'ou novou konfliktnou líniou je už vyššie spomínaný konflikt medzi materializmom a postmaterializmom.

Vplyvom ekonomickej a migračnej krízy v Európe došlo podl'a Hoogheho a Marksa (2017) k vyprofilovaniu d’alšej konfliktnej línie, ktorú nazvali ako transnacionálnu konfliktnú líniu. Táto konfliktná línia stavia na štiepení spoločnosti na zástancov európskej integrácie a podpory migrantom a zástancov protiimigračných myšlienok a euroskeptikov. Autori podotýkajú, že sa tejto konfliktnej línii nedokážu vel'mi prispôsobit' tradičné mainstreamové strany. Hlavnými politickými protagonistami tejto konfliktnej línie sú na jednej strane proeurópske strany zelených a liberálov a na druhej sa nachádzajú euroskeptické populisticko-radikálne pravicové strany.

Vzhl’adom na to, že teória konfliktných línii bola primárne konštruovaná pre západoeurópske štáty, bolo otázkou, ako teória funguje v priestore postsocialistických krajín strednej a východnej Európy. Roskin (1993) tvrdil, že z dôvodu neustálych zmien po páde komunizmu nie je možné aplikovat' teóriu konfliktných línií pre tieto krajiny. Evans a Whitefield (1995) aplikovali teóriu konfliktných línii bez špeciálnych zmien. Medzi tieto dva postoje sa radí tretia skupina autorov, ktorí aplikovali upravenú teóriu konfliktných línii (napríklad Kitschelt 1995; Evans - Whitefield 1998, 2000; Hloušek - Kopeček 2004).

Hloušek a Kopeček (2004) prišli pre priestor postsocialistických krajín s konfliktnými líniami transformácie. Prvou konfliktnou líniou po páde socializmu bol spor o podobu budúceho režimu. Táto línia popisovala konflikt medzi komunistickým režimom a protirežimovou opozíciou, pričom dôležitými ovplyvňujúcimi faktormi boli podoba a sila antikomunistického hnutia a schopnost' komunistickej strany sa transformovat' na sociálnodemokratické subjekty. Táto konfliktná línia pôsobila väčšinou len krátko v prvých rokoch transformácie krajín k demokratickým režimom, ale v niektorých krajinách pretrváva $\mathrm{v}$ reziduálnej podobe, kedy býva označovaná ako konfliktná línia medzi komunizmom a antikomunizmom (Hloušek - Kopeček 2004). V niektorých krajinách sa spor o podobu režimu objavil aj v neskoršom období, kde ako 
príklad poslúži konflikt medzi mečiarizmom a antimečiarizmom v druhej polovici 90. rokov 20. storočia na Slovensku (Madleňák 2012).

Ďalšou konfliktnou líniou je socioekonomická konfliktná línia transformácie. Táto línia vznikla v dôsledku ekonomickej transformácie, pri ktorej vznikali skupiny obyvatel'stva prosperujúce na tejto transformácii a skupiny objektívne alebo subjektívne strádajúce. Táto konfliktná línia bola zárodkom klasickej konfliktnej línie robotníci verzus zamestnávatelia, respektíve l’avica verzus pravica, pretože pravicové konzervatívne a liberálne politické strany preferovali rýchlejšiu transformáciu riadenej ekonomiky na tržnú a sociálnodemokratické strany skôr zohl'adňovali sociálne dopady transformácie. Táto línia bola najvýraznejšia $\mathrm{v}$ štátoch, $\mathrm{v}$ ktorých ekonomická transformácia prebehla najd'alej (ako napríklad Česko, Pol'sko, Slovinsko).

Tret’ou líniou je nacionalistická konfliktná línia transformácie. Táto konfliktná línia súvisí s konfliktnou líniou centrum verzus periféria, pričom má výraznú etnickú a nacionalistickú podobu. Proti sebe stojí majoritný národ a národnostné menšiny. Táto konfliktná línia je silná $\mathrm{v}$ štátoch bývalej Juhoslávie, v Lotyšsku alebo na Slovensku. Hloušek a Kopeček poznamenávajú, že okrem popísaných konfliktných línii sú v postsocialistických krajinách zretel'né konfliktné línie cirkev verzus štát, mesto verzus vidiek a materializmus verzus postmaterializmus. Pri konfliktnej línii mesto verzus vidiek je otázne, či je možné ju chápat' v pôvodnom význame Lipseta a Rokkana, alebo či v súčasnosti skôr viac nereflektuje konzervatívno-liberálnu konfliktnú líniu (Hloušek Kopeček 2004).

Okrem teórie konfliktných línií existujú aj iné koncepty, ktoré sa snažia vysvetlit' rozloženie podpory politických strán. Jednou z nich je teória rozhorčenia. Táto teória má dlhodobú tradíciu v odbornej literatúre o sociálnych hnutiach. Základná myšlienka teórie je, že osobná nespokojnost' a rozhorčenie stimuluje u voličov politickú participáciu a protestnú vol'bu počas volieb (Kern et al. 2015). Klandermans, Roefs a Olivier definujú rozhorčenie (vangličtine grievance) ako „pocit nespokojnosti s dôležitými aspektami života" (Klandermans et al. 2001: 42) ako je životný štandard, príjem, zamestnanie, bývanie, bezpečnost' a d'alšie. Pocit rozhorčenia u obyvatel'ov vyvolávajú skutočné zmeny a postavenie voliča (jeho začlenenie do určitej sociálnej triedy, rasové, náboženské zaradenie, strata zamestnania), subjektívne pocity voliča (ako sa cíti v porovnaní s ostatnými, dôvera vo vládu) a z predpokladaných problémov, ktoré volič očakáva. Subjektívne pocity voliča a jeho predpokladané problémy vytvárajú relatívnu depriváciu, ktorá sa dá charakterizovat' ako rozpor medzi tým, aké ma volič predstavy o tom, čo si zaslúži a tým, čo podl'a seba môže skutočne získat' (Klandermans et al. 2008). Relatívna deprivácia jedného človeka sa môže postupom času vyvinút' do skupinovej 
relatívnej deprivácie, pri ktorej sa nejaká sociálna skupina cíti znevýhodnená oproti iným.

Relatívnu depriváciu voličov využívajú populisticko-radikálne pravicové strany. Ivarsflaten (2008) popisuje tri typy rozhorčenia voličov, ktoré môžu zvyšovat' popularitu týchto strán. Prvým typom je rozhorčenie z ekonomickej situácie, kde voliči volia populistickú radikálnu pravicu, pretože nie sú spokojní so svojím ekonomickým postavením, ekonomickou situáciou štátu a mierou nezamestnanosti. Kern, Marien a Hooghe (2015) vo svojom výskume potvrdili, že ekonomická kríza medzi rokmi 2007 a 2009 a nárast nezamestnanosti $\mathrm{v}$ Európe spôsobil i nárast rozhorčenia u voličov prejavujúci sa ich zvýšenou politickou mobilizáciou a odovzdávaním protestných hlasov aj populisticko-radikálnym pravicovým stranám. Rozhorčenie môže vyvolávat' nielen aktuálna ekonomická situácia, ale tiež deprivácia z ekonomickej situácie v minulosti. Takže sa môže ekonomická situácia voliča alebo regiónu zlepšovat', ale stále je viditel'né rozhorčenie z minulých rokov (Greve et al. 2021). Druhým typom rozhorčenia, ktorý využíva populistická radikálna pravica, je rozhorčenie voličov z vlády. Tento typ rozhorčenia je úzko prepojený s problematikou korupcie politikov. To vedie $\mathrm{k}$ tomu, že sa voliči rozhodujú udel'ovat' protestné hlasy stranám, ktoré tvrdia, že zakročia proti korupcii. Tretím, a podl'a Ivarsflatenovej (2008) najdôležitejším typom rozhorčenia pre západoeurópske populisticko-radikálne pravicové strany, je rozhorčenie z imigrácie. Tento vplyv potvrdzujú výskumy Shuermansa a de Maesschalcka (2010) v Belgicku a van Genta, Jansena a Smitsa (2014) v Holandsku. Oba výskumy poukázali na to, že väčšia podpora pre populisticko-radikálne pravicové strany bola $\mathrm{v}$ oblastiach $\mathrm{s}$ menším počtom imigrantov a väčšiu úlohu, ako reálny počet cudzincov, zohrávalo rozhorčenie a strach z možného príchodu imigrantov do ich regiónu.

\section{Metodika a použité dáta}

Pre diskusiu o výpovednej schopnosti vyššie predstavených teórií v podmienkach českej a slovenskej spoločnosti sú formulované tri hypotézy, ktoré, posudzované spoločne, umožnia potvrdit' explanačnú silu vyššie zmienených teórií a súčasne umožnia identifikovat' hlavné faktory podmieňujúce geografické rozdiely vo volebnej podpore populistickej radikálnej pravice. $Z$ diskusie je zrejmé, že sa tieto teórie vzájomne nevylučujú, čiastočne sa prekrývajú a v niektorých prípadoch sa opierajú o rovnaké alebo obdobné indikátory. U jednotlivých teórií sa môže iba posudzovat' ich relatívny prínos k explanácii vzt’ahu medzi mierou volebnej podpory pre populistickú radikálnu pravicu a sociálnymi, ekonomickými, sídelnými a inými charakteristikami regiónov vyjadrených pomocou empirických indikátorov. Hypotézy sú formulované tak, aby umožnili čo najlepšie posúdit' vypovedajúcu schopnost' teórií, vychádzali 
zo zistení predchádzajúcich autorov a aby ich bolo možné potvrdzovat' pomocou empirických indikátorov na úrovni okresov.

H1: Volebná podpora populistickej radikálnej pravice je vyššia v okresoch $s$ vyššim podielom veriacich obyvatelov, s nižším podielom podnikatelov so zamestnancami a s nižšou mierou urbanizácie.

Pri potvrdení platnosti hypotézy H1 je pre vysvetlenie geografických rozdielov vo volebnej podpore populistickej radikálnej pravice relevantná pôvodná teória konfliktných línií Lipseta a Rokkana. Jednotlivé indikátory reprezentujú tri zo štyroch konfliktných línií. Konfliktná línia centrum verzus periféria nie je zaradená do hypotézy, pretože podla Pinka a Vody (2012) neexistuje v priestore Česka politická periféria a na Slovensku ju reprezentujú iba mad'arské politické subjekty, ktoré viac reprezentuje nacionalistická konfliktná línia transformácie (Hloušek - Kopeček 2004).

H2: Volebná podpora populistickej radikálnej pravice je vyššia v okresoch $s$ vyššim podielom Českého respektíve Slovenského obyvatel'stva a s nižšou volebnou účastou vo vol'bách do Európskeho parlamentu.

Ciel'om hypotézy $\mathrm{H} 2$ je potvrdit' platnost' niektorých upravených konfliktných línií v podmienkach Česka a Slovenska. Skúma sa platnost' nacionalistickej konfliktnej línie transformácie a konfliktnej línie medzi eurooptimistickými a euroskeptickými postojmi. Treba však poznamenat', že i kedy sa ukáže vyššia volebná podpora populistickej radikálnej pravice i vokresoch s vyššou volebnou účast'ou vo vol'bách do Európskeho parlamentu, neznamená to automaticky zavrhnutie hypotézy $\mathrm{H} 2$, pretože najmä v európskych vol'bách v roku 2019 populisticko-radikálne pravicové strany sa snažili mobilizovat' svojich voličov. Táto mobilizácia mala ale za ciel' oslabit' fungovanie Európskej únie a posilnit' euroskeptické hnutia.

H3: Volebná podpora populistickej radikálnej teórie je vyššia v okresoch $s$ vyššou mierou nezamestnanosti a s lepšou nezamestnanostou než mali pred desiatimi rokmi.

Hypotéza H3 sa snaží potvrdit' teóriu rozhorčenia, konkrétne rozhorčenie z aktuálnej a zároveň aj z minulej ekonomickej situácie.

$\mathrm{Na}$ hodnotenie potenciálneho vplyvu vybraných empirických indikátorov na výšku volebnej podpory populisticko-radikálnych pravicových strán v okresoch Česka a Slovenska je použitá viacnásobná lineárna regresia. Tento univerzálny štatistický model umožňuje $\mathrm{v}$ súbore nezávislých premenných $x_{1}, \ldots, x_{n}$ identifikovat' premenné, ktoré významne vysvetl'ujú variabilitu závislej premennej $Y$ a zistit', akú čast' variability závislé premenné dokážu nezávislé premenné vysvetlit' a tiež posúdit' relatívnu dôležitost' každej z nezávislých premenných (Rabušic 2004). Ďalej je použitá metóda váženej regresnej analýzy. Vstupné premenné sú vážené počtom voličov zapísaných vo volebných zoznamoch obce. Pre poradie vstupu nezávislých premenných do regresného modelu je 
zvolená štandardná metóda (ENTER). Prínos jednotlivých premenných pre vysvetlenie variability volebnej účasti sa hodnotí štandardizovaným regresným koeficientom (beta). Čím vyššia je absolútna hodnota štandardizovaného koeficientu, tým je daná nezávislá premenná významnejšia pre vysvetlenie variability závislé premenné (Hendl 2012).

Analyzovaná je volebná podpora populisticko-radikálnych pravicových strán v parlamentných vol'bách konaných v rokoch 2010 až 2020 v Česku a na Slovensku a to na úrovni okresov. V rámci Česka sa jedná o vol'by v rokoch 2010, 2013 a 2017, kedy je analyzovaná volebná podpora Dělnické strany sociální spravedlnosti (d’alej DSSS) vo vol'bách v rokoch 2010, 2013 a 2017, hnutia Úsvit př́mé demokracie Tomia Okamury (d’alej Úsvit) za rok 2013 a hnutia Svoboda a prímá demokracie (d’alej SPD) vo vol'bách v roku 2017. Na Slovensku sa jedná o vol'by v rokoch 2010, 2012, 2016 a 2020, kedy je analyzovaná volebná podpora Slovenskej národnej strany (d’alej SNS) a strany Kotlebovci - L’udová strana Naše Slovensko (d’alej LSNS) v rokoch 2010, 2012, 2016 a 2020 a strany VLASŤ vo vol'bách v roku 2020. Vybrané strany vo svojich predvolebných programoch spíňali všetky tri znaky populistickej radikálnej pravice podl'a Mudda (2007), ako sú nativizmus, silný štát a populizmus. Z tohto dôvodu nebola za populistickú radikálnu pravicu označená napríklad slovenská strana Sme rodina, ktorá sa síce v rámci európskeho politického spektra sama hlási k tomuto typu strán, avšak z hl'adiska Muddeho kritérií spĺn̆a iba podmienky populizmu a čiastočne nativizmu.

Údaje o volebnej podpore populisticko-radikálnych politických strán v Česku sú získané z Českého statistického úřadu (2017a, 2017b, 2017c). Údaje o volebných výsledkoch na Slovensku pochádzajú zo Štatistického úradu Slovenskej republiky $(2010,2012,2016,2020)$. Nezávislé premenné sú vybrané tak, aby sa vzt’ahovali k tým aspektom sociálnej štruktúry okresov, s ktorými pracujú spomenuté teórie konfliktných línií a rozhorčenia. K zabráneniu multikolinearity nezávislých premenných sú použité dve metódy. Najskôr dochádza na základe korelačnej analýzy $\mathrm{k}$ vylúčeniu premenných $\mathrm{s}$ vysokou párovou koreláciou s niektorou d’alšou nezávislou premennou. Následne je testom multikolinearity overené, že žiadna z nezávislých premenných nemá hodnotu tolerancie menšiu ako 0,2 a ani hodnotu faktoru zvyšujúceho rozptyl (VIF) vyššiu než 5 (Rabušic 2004).

Je vybraných sedem nezávislých premenných. Podiel veriacich obyvatelov (VERIACI), podiel podnikatelov zo zamestnancami $k$ počtu ekonomicky aktivneho obyvatel'stva (PODNIK) a miera urbanizácie (URBAN) sú zvolené pre testovanie platnosti klasickej teórie konfliktných línií. S týmito premennými ako ukazovatel'mi teórie konfliktných línií v priestore Česka a Slovenska pracovali napríklad Madleňák (2012) alebo Pink a Voda (2012). Ako relevantné ukazovatele pre verifikáciu modifikovaných teórií konfliktných línií sú 
použité podiel obyvatelov českej, respektíve slovenskej národnosti (ČEŠI/SLOVÁCI) a volebná účast' vo vol'bách do Európskeho parlamentu (EURO). Hooghe a Marks (2017) a Vasilopoulou (2018) poukazujú na to, že euroskeptickí voliči populisticko-radikálnych pravicových strán majú menší záujem o vol'by do Európskeho parlamentu, takže volebná účast' do tejto inštitúcie môže byt' vhodným ukazovatel'om podpory tejto politickej rodiny. Avšak na druhú stranu tiež podotýkajú, že v niektorých prípadoch sa populistická radikálna pravica snaží mobilizovat' voličov, aby išla volit' vo vol'bách do Európskeho parlamentu. Miera nezamestnanosti (NEZAM) a index zmeny nezamestnanosti za desat' rokov (INEZ10) slúžia v analýzach ako ukazovatele platnosti teórie rozhorčenia. Index zmeny nezamestnanosti za desat' rokov je vypočítaný ako rozdiel miery nezamestnanosti v roku volieb a miery nezamestnanosti z pred desiatich rokov. Pre porovnatel'nost' hodnôt medzi sebou je miera nezamestnanosti relativizovaná $\mathrm{k}$ celoštátnemu priemeru $\mathrm{v}$ danom roku. Ivarsflatenova (2008) a Kern, Marien a Hooghe (2015) považujú ukazovatel' nezamestnanosti za jeden znak, ktorý naznačuje ekonomické rozhorčenie voličov. A Greve, Fritsch a Wyrwich (2021) považujú za dôležité sledovat' aj dlhodobý trend vývoja ekonomickej situácie v regióne.

Zdrojom dát o sociálnej štruktúre sú databázy Českého statistického úřadu a Štatistického úradu Slovenskej republiky vychádzajúce zo sčítania obyvatel'stva v roku 2011 (Český statistický úřad 2021, Štatistický úrad SR 2021a). Zo sčítania sú získane údaje o náboženskej (VERIACI), ekonomickej (PODNIK) a národnostne štruktúre obyvatel'stva (ČEŠI/SLOVÁCI). Z priebežnej evidencie štatistických úradov pochádzajú údaje o miere urbanizácie (Český statistický úrad 2021, Štatistický úrad SR 2021a) a o volebnej účasti do Európskeho parlamentu z rokov 2009, 2014 a 2019 (Český statistický úřad 2020, Štatistický úrad SR 2021b). Volebná účast' do Európskeho parlamentu z roku 2009 vstupovala do regresných modelov pre parlamentné vol'by v roku 2010. Volebná účast' z roku 2014 zas pre parlamentné vol'by v rokoch 2012, 2013 a 2016 a volebná účast' do Európskeho parlamentu z roku 2019 vstupovala do regresného modelu pre parlamentné vol'by v rokoch 2017 a 2020. Údaje o miere urbanizácie sú brané za rok, v ktorom sa konali vol'by. Údaje o nezamestnanosti (NEZAM, INEZ10) sú získane zo štatistík úradov práce v Česku (Ministerstvo práce a sociálních věcí 2021) a na Slovensku (Ústredie práce, sociálnych vecí a rodiny 2021). Sú vypočítané ich trojmesačné priemery, a to ako priemer mesiaca, $\mathrm{v}$ ktorom sa konali vol'by a predchádzajúcich dvoch mesiacov.

$\mathrm{Z}$ vyššie spomenutého vychádza to, že táto práca analyzuje agregátne dáta. Problémom týchto dát je, že často neponúkajú konkrétne informácie, ktoré výskumník požaduje, a preto musí použit pri analýze iné podobné premenné, ktoré sú dostupné. Ďalším problémom je aktuálnost' dát. Niektoré dáta sú 
dostupné len zo sčítania obyvatel'stva, ktoré sa koná raz za desat' rokov. Pri týchto dátach sa tiež musí dávat' pozor na to, aby nedochádzalo k ekologickej chybe pri interpretácii, kedy štatistický vzt’ah významný na agregátnej úrovni nemusí byt' významný na úrovni jednotlivca (Kostelecký - Čermák 2002). Všetky tieto problémy je potreba zohl'adnit' pri interpretácii výsledkov.

\section{Výsledky}

Z regresných modelov vyplýva, že až na volebnú podporu stany DSSS v roku 2017, je najvýznamnejším faktorom vysvetl'ujúcim volebnú podporu populisticko-radikálnych pravicových strán v Českú volebná účast' do Európskeho parlamentu (pozri tabul'ky 1 a 2). S rastom podielu veriacich l'udí v okresoch je pozorované zníženie volebnej podpory strany DSSS vo všetkých troch vol'bách. Naproti tomu u strany Úsvit v roku 2013 je trend opačný. Vo vol'bách v rokoch 2010 a 2013 má populistická radikálna pravica väčšiu podporu v okresoch s vyšším zastúpením podnikatelov so zamestnancami. Strana SPD v roku 2017 má vyššiu volebnú podporu v okresoch s nižším podielom obyvatel'ov českej národnosti, čo môže poukazovat' na jej vyššiu podporu na Morave a v Sliezsku. Strana DSSS má vyššiu volebnú podporu v okresoch, kde je nižšia miera nezamestnanosti oproti stavu z pred desiatich rokov.

Tabul'ka č. 1: Výsledky regresných analýz pre DSSS vo vol'bách v rokoch 2010 až 2017

\begin{tabular}{|c|c|c|c|c|c|c|}
\hline \multirow[b]{2}{*}{ Premenné } & \multicolumn{2}{|c|}{ Vol'by v roku 2010} & \multicolumn{2}{|c|}{ Vol'by v roku 2013} & \multicolumn{2}{|c|}{ Vol'by v roku 2017} \\
\hline & beta & $\mathbf{p}$ & beta & $\mathbf{p}$ & beta & $\mathbf{p}$ \\
\hline VERIACI & $-0,39$ & 0,00 & $-0,44$ & 0,00 & $-0,40$ & 0,00 \\
\hline PODNIK & 0,20 & 0,05 & 0,20 & 0,04 & $-0,02$ & 0,90 \\
\hline URBAN & 0,14 & 0,08 & 0,13 & 0,09 & $-0,04$ & 0,67 \\
\hline ČEŠ́I & 0,04 & 0,69 & 0,05 & 0,57 & 0,06 & 0,54 \\
\hline EURO & $-0,58$ & 0,00 & $-0,65$ & 0,00 & $-0,28$ & 0,16 \\
\hline NEZAM & 0,27 & 0,06 & 0,13 & 0,26 & 0,13 & 0,35 \\
\hline \multirow[t]{2}{*}{ INEZ10 } & $-0,13$ & 0,08 & $-0,15$ & 0,08 & $-0,39$ & 0,00 \\
\hline & $\mathbf{R}^{2}$ & 0,69 & $\mathbf{R}^{2}$ & 0,75 & $\mathbf{R}^{2}$ & 0,62 \\
\hline
\end{tabular}

Zdroj dát: Český statistický úřad 2017a, 2017b, 2017c

Na Slovensku je pre všetky analyzované populisticko-radikálne pravicové strany vo všetkých vol'bách významným vysvetl'ujúcim faktorom podiel obyvatel'ov so slovenskou národnost'ou (pozri tabul'ky 3 až 5). V okresoch s vyšším podielom Slovákov je i vyššia podpora populistickej radikálnej pravice. S rastúcou mierou nezamestnanosti rastie i volebná podpora strany LSNS vo všetkých skúmaných vol'bách a tiež i volebná podpora strany SNS 
v roku 2020. Stana L'SNS v rokoch 2016 a 2020 a strana SNS vo vol'bách v roku 2020 majú vyššiu volebnú podporu aj v okresoch, kde je nižšia miera nezamestnanosti oproti stavu z pred desiatich rokov. Volebná účast' do Európskeho parlamentu negatívne ovplyvňuje volebnú podporu strán L'SNS a VLASŤ vo vol'bách v roku 2020. Negatívne tiež ovplyvňuje podiel veriacich volebnú podporu L'SNS v rokoch 2010 a 2012. Naopak strany SNS a VLASŤ majú v roku 2020 vyššiu volebnú podporu v okresoch s vyšším podielom veriacich. Pre stranu VLASŤ je významným faktorom ovplyvňujúcim jej volebnú podporu i miera urbanizácie.

Tabul'ka č. 2: Výsledky regresných analýz pre Úsvit vo vol'bách v roku 2013 a SPD vo vol'bách v roku 2017

\begin{tabular}{lcccc}
\hline & \multicolumn{2}{c}{ Vol'by v roku 2013 } & \multicolumn{2}{c}{ Vol'by v roku 2017 } \\
\cline { 2 - 5 } Premenné & beta & $\mathbf{p}$ & beta & $\mathbf{p}$ \\
\hline VERIACI & 0,23 & 0,02 & 0,08 & 0,21 \\
PODNIK & 0,20 & 0,07 & 0,02 & 0,74 \\
URBAN & $-0,12$ & 0,07 & $-0,04$ & 0,46 \\
ČEŠI & $-0,06$ & 0,56 & $-0,24$ & 0,00 \\
EURO & $-1,02$ & 0,00 & $-0,87$ & 0,00 \\
NEZAM & $-0,01$ & 0,94 & 0,03 & 0,72 \\
INEZ10 & 0,20 & 0,04 & 0,02 & 0,76 \\
\hline & $\mathbf{R}^{2}$ & 0,70 & $\mathbf{R}^{2}$ & 0,86 \\
\hline
\end{tabular}

Zdroj dát: Český statistický úřad 2017a, 2017b, 2017c

Tabul'ka č. 3: Výsledky regresných analýz pre SNS vo vol'bách v rokoch 2010 až 2016

\begin{tabular}{llclccc}
\hline & \multicolumn{2}{l}{ Vol'by v roku 2010 } & \multicolumn{2}{c}{ Vol'by v roku 2012 } & \multicolumn{2}{c}{ Vol'by v roku 2016 } \\
\cline { 2 - 7 } Premenné & beta & $\mathbf{p}$ & beta & $\mathbf{p}$ & beta & $\mathbf{p}$ \\
\hline VERIACI & 0,11 & 0,48 & 0,01 & 0,96 & 0,11 & 0,37 \\
PODNIK & $-0,04$ & 0,84 & 0,12 & 0,59 & $-0,02$ & 0,90 \\
URBAN & $-0,25$ & 0,11 & $-0,21$ & 0,23 & $-0,13$ & 0,36 \\
SLOVÁCI & 0,67 & 0,00 & 0,59 & 0,00 & 0,71 & 0,00 \\
EURO & 0,16 & 0,24 & $-0,18$ & 0,27 & $-0,13$ & 0,32 \\
NEZAM & 0,02 & 0,93 & $-0,09$ & 0,70 & 0,08 & 0,56 \\
INEZ10 & $-0,05$ & 0,74 & 0,11 & 0,42 & 0,01 & 0,92 \\
\hline & $\mathbf{R}^{2}$ & 0,44 & $\mathbf{R}^{2}$ & 0,39 & $\mathbf{R}^{2}$ & 0,58 \\
\hline
\end{tabular}

Zdroj dát: Štatistický úrad SR 2010, 2012, 2016

Sociológia 53, 2021, č. 6 
Tabul'ka č. 4: Výsledky regresných analýz pre LSNS vo vol'bách v rokoch 2010 až 2016

\begin{tabular}{lcccccc}
\hline & \multicolumn{2}{c}{ Vol'by v roku 2010 } & \multicolumn{2}{c}{ Vol'by v roku 2012 } & \multicolumn{2}{c}{ Vol'by v roku 2016 } \\
\cline { 2 - 7 } Premenné & beta & $\mathbf{p}$ & beta & $\mathbf{p}$ & beta & $\mathbf{p}$ \\
\hline VERIACI & $-0,26$ & 0,10 & $-0,41$ & 0,01 & $-0,09$ & 0,36 \\
PODNIK & $-0,34$ & 0,10 & $-0,17$ & 0,45 & $-0,07$ & 0,65 \\
URBAN & $-0,07$ & 0,68 & $-0,22$ & 0,22 & $-0,26$ & 0,02 \\
SLOVÁCI & 0,27 & 0,10 & 0,38 & 0,02 & 0,70 & 0,00 \\
EURO & 0,08 & 0,61 & $-0,03$ & 0,84 & $-0,12$ & 0,25 \\
NEZAM & 0,48 & 0,07 & 0,47 & 0,06 & 0,37 & 0,00 \\
INEZ10 & $-0,11$ & 0,50 & $-0,11$ & 0,45 & $-0,17$ & 0,06 \\
\hline
\end{tabular}

Zdroj dát: Štatistický úrad SR 2010, 2012, 2016

Tabul'ka č. 5: Výsledky regresných analýz pre SNS, LSNS a VLASŤ vo vol'bách v roku 2020

\begin{tabular}{lcccccc}
\hline & \multicolumn{2}{c}{ SNS } & \multicolumn{2}{c}{ LSNS } & \multicolumn{2}{c}{ VLAST̃ } \\
\cline { 2 - 6 } Premenné & beta & $\mathbf{p}$ & beta & $\mathbf{p}$ & beta & $\mathbf{p}$ \\
\hline VERIACI & 0,37 & 0,00 & $-0,15$ & 0,13 & 0,29 & 0,02 \\
PODNIK & 0,09 & 0,61 & $-0,12$ & 0,41 & 0,03 & 0,87 \\
URBAN & 0,13 & 0,32 & $-0,14$ & 0,20 & 0,43 & 0,00 \\
SLOVÁCI & 0,74 & 0,00 & 0,68 & 0,00 & 0,70 & 0,00 \\
EURO & $-0,21$ & 0,21 & $-0,31$ & 0,03 & $-0,44$ & 0,02 \\
NEZAM & 0,40 & 0,04 & 0,52 & 0,00 & $-0,01$ & 0,96 \\
INEZ10 & $-0,31$ & 0,03 & $-0,41$ & 0,00 & 0,19 & 0,22 \\
\hline & $\mathbf{R}^{\mathbf{2}}$ & 0,62 & $\mathbf{R}^{\mathbf{2}}$ & 0,74 & $\mathbf{R}^{\mathbf{2}}$ & 0,57 \\
\hline
\end{tabular}

Zdroj dát: Štatistický úrad SR 2020

Ked' sa porovnajú regresné modely volebnej podpory českých a slovenských populisticko-radikálnych pravicových strán, je vidno určité podobnosti, ale aj rozdiely. V Česku najvýraznejšie ovplyvňuje volebnú podporu $\mathrm{v}$ okresoch výška volebnej účasti do Európskeho parlamentu. Naproti tomu na Slovensku významne ovplyvňuje volebnú podporu iba u dvoch populistickoradikálnych pravicových strán $\mathrm{v}$ roku 2020. Na Slovensku najvýznamnejší faktor národnosti je v Česku významný len pre stranu SPD v roku 2017. V obidvoch krajinách existujú strany, ktoré majú vyššiu volebnú podporu v okresoch s vyšším podielom veriacich (Úsvit v roku 2013, SNS a VLASŤ v roku 2020) a potom strany, ktoré ju majú v týchto okresoch nižšiu (DSSS a L'SNS v roku 2010 a 2012). Populisticko-radikálne pravicové strany majú zvyčajne vyššiu volebnú podporu v okresoch, kde došlo k zlepšeniu stavu 
nezamestnanosti oproti situácii z pred desiatich rokov. Opačne to má len hnutie Úsvit vo vol'bách v roku 2013.

Dôležitým zistením je to, že postupom času dochádza $\mathrm{k}$ zvyšovaniu podielu variability závisle premennej vysvetlenej regresným modelom, čo je indikované nárastom koeficientu determinácie $\left(R^{2}\right)$. Výnimkou sú len regresné modely za vol'by v roku 2012 na Slovensku a regresný model strany DSSS v roku 2017. Regresné modely s vyšším koeficientom determinácie majú vyššiu vypovedaciu schopnost', čo svedčí o tom, že rozdiely medzi okresmi Česka a Slovenska sa v čase stávajú viac podmienené sledovanými sociálnoekonomickými indikátormi.

\section{Diskusia a záver}

Hlavným ciel'om práce je pomocou teórií a predchádzajúcich zistení identifikovat' sociálne faktory, ktoré potencionálne vysvetl'ujú rozloženie volebnej podpory populistických radikálnych strán v Česku a na Slovensku. $\mathrm{K}$ tomu sú vytvorené tri hypotézy H1, H2, H3.

Hypotéza H1 overuje platnost' klasickej teórie konfliktných línií pomocou troch premenných, ktoré reprezentujú tri konfliktné línie. U konfliktnej línie cirkev verzus štát sa ukazuje, že DSSS vo všetkých skúmaných vol'bách a L'SNS vo vol'bách v roku 2010 a 2012 majú nižšiu podporu v okresoch s vyšším podielom veriacich a strany SNS a VLASŤ v roku 2020 a Úsvit v roku 2013 naopak vyššiu. To poukazuje na to, že skúmaná konfliktná línia ovplyvňuje volebnú podporu populisticko-radikálnych pravicových strán, ale taktiež záleží na postoju jednotlivých strán k cirkvi a primárne ku krest’anstvu a ako vel'mi je pre nich táto téma dôležitá (Mareš 2003; Mikuš - Gurňák 2016, 2019). Význam premenných zastupujúcich konfliktné línie robotníci verzus zamestnávatelia a mesto verzus vidiek nie je zvyčajne výraznejší pre vysvetlenie regresného modelu. Z týchto výsledkov vyplýva, že hypotéza H1 je vyvrátená.

Naproti tomu premenné, ktoré vychádzajú z hypotézy H2, patrí k najvýznamnejším faktorom ovplyvňujúcim volebnú podporu populisticko-radikálnych pravicových strán. V Česku to je premenná výšky volebnej účasti vo vol'bách do Európskeho parlamentu. Toto môže ukazovat' dôležitost' konfliktnej línie eurooptimizmus verzus euroskepticizmus pre pochopenie volebnej podpory populistickej radikálnej pravice, ktorá sa výrazne stavia na stranu kritikov a odporcov Európskej únie (Vasilopoulou 2018). Naproti tomu na Slovensku je tento faktor významný až vo vol'bách v roku 2020 a ovel'a väčšiu dôležitost' má podiel slovenského obyvatel'stva $\mathrm{v}$ okresoch. To poukazuje na platnost' nacionalistickej konfliktnej línie transformácie na Slovensku. V Č̉esku nie je táto premenná tak významná preto, že na rozdiel od Slovenska nie je v Česku výrazná národnostná menšina (Hloušek - Kopeček 2004). Zaujímavé 
je, že aj napriek zvýšenej snahe mobilizovat' svojich voličov v Európskych vol'bách v roku 2019 sa u populistickej radikálnej pravice neukázal pozitívny vzt'ah medzi volebnou účast'ou vo vol'bách do Európskeho parlamentu a volebnou podporou týchto strán v národných vol'bách. Hypotéza H2 sa v priestore Česka a Slovenska potvrdila.

Hypotéza H3 sa snaží overit' platnost' teórie rozhorčenia, teda konkrétne rozhorčenie z ekonomickej situácie. Ukazuje sa, že populisticko-radikálne pravicové strany, najmä na Slovensku, majú vyššiu podporu vokresoch s vyššou mierou nezamestnanosti. Tiež sa ukazuje, že niektoré strany majú vyššiu podporu v okresoch, u ktorých došlo k zlepšeniu stavu nezamestnanosti oproti situácií z pred desiatich rokov. To môže naznačovat', že v Česku a na Slovensku existuje deprivácia z minulej ekonomickej situácie, aj ked' si daný okres ekonomicky polepšil (Greve et al. 2021). Tieto skutočnosti potvrdzujú hypotézu H3. Súčasne je však treba pripomenút', že nezamestnanost' môže odrážat' aj vplyv iných faktorov, ako je napríklad vzdelanostná štruktúra alebo geografická poloha a vzt’ah medzi volebnou podporou populistickej radikálnej pravice a nezamestnanost'ou preto nie je nezávislý na iných podmieňujúcich faktoroch.

Výsledky analýz ukazujú, že populistická radikálna pravica v Česku a na Slovensku má typické znaky populistickej radikálnej pravice v strednej a východnej Európe, ktorými ich charakterizuje Mudde (2005) alebo Bustiková (2018). Ide napríklad o dôraz na vyzdvihovanie vlastného národa alebo poukazovanie na zlú ekonomickú situáciu a vyššiu nezamestnanost'. To je v súlade so skoršími prácami, ktoré analyzovali volebnú podporu týchto strán v skúmanej oblasti (Mareš 2003; Mikuš - Gurňák 2012, 2019). Tiež je viditel'ný istý posun populisticko-radikálnych pravicových strán v Česku a na Slovensku k znakom charakteristickým pre populistickú radikálnu pravicu v západnej Európe, na čo poukazujú v svojich prácach Polyakova (2015) alebo Pytlas (2018). Konkrétne to je vidiet' u volebnej účasti do Európskeho parlamentu čo môže byt' znakom euroskepticizmu (Vasilopoulou 2018). Zaujímavé je, že tento ukazovatel' bol významný v Česku po celú skúmanú dobu, zatial' čo na Slovensku sa stal významným faktorom až v posledných skúmaných vol'bách v roku 2020.

Empirickú verifikáciu všetkých uvedených hypotéz je treba považovat' za sprostredkovanú a podmienenú aj inými faktormi okrem tých, ktoré hypotézy podporujú. Preto sa nedá povedat', že rozloženie volebnej podpory populistickej radikálnej pravice v Česku a na Slovensku sa dá vysvetlit' pomocou jednej konkrétnej teórie. Uskutočnená analýza naopak ukazuje, že k vysvetleniu rozloženia volebnej podpory okrem klasickej teórie konfliktných línií Lipseta a Rokkana, je treba brat' v úvahu aj d’alšie konfliktné línie reflektujúce vývoj v druhej polovici 20. storočia a špecifiká prostredia strednej a východnej 
Európy. Tiež sa potvrdilo, že je vhodné pracovat' aj s inými teóriami a konceptmi, ako v tomto prípade s teóriou rozhorčenia, ktoré ponúknu d’alšie možnosti vysvetlenia rozloženia podpory populistickej radikálnej pravice. V každom prípade zostane populistická radikálna pravica v Česku a na Slovensku významným hráčom vo vol'bách a preto je dôležité venovat' jej pozornost' v sociologickom i geografickom výskume.

Dominik Kevický je študentom doktorského štúdia sociálnej geografie a regionálneho rozvoja na Přrirodovédecké fakultě Masarykovej univerzity v Brne. Na rovnakej univerzite vyštudoval magisterský obor Sociálna geografia a regionálny rozvoj so špecializáciou na volebnú geografiu. Vedecky sa venuje geografickým aspektom volebnej účasti a priestorovej nerovnomernosti podpory populistickej radikálnej pravice.

\section{LITERATÚRA}

BORNSCHIER, S., 2018: Globalization, Cleavages and the Radical Right. In: Rydgren, J. (ed.): The Oxford Handbook of the Radical Right. New York: Oxford University Press. s. 311-347.

BUSTIKOVÁ, L., 2018: The Radical Right in Eastern Europe. In: Rydgren, J. (ed.): The Oxford Handbook of the Radical Right. New York: Oxford University Press. s. 799-821.

ČESKÝ STATISTICKÝ ÚŘAD, 2017a: Volby do Poslanecké sněmovny Parlamentu České republiky konané ve dnech 28.05. - 29.05.2010. [online]. [citované 31. 7. 2020]. Dostupné na: https://volby.cz/pls/ps2010/ps.

ČESKÝ STATISTICKÝ ÚR̆AD, 2017b: Volby do Poslanecké sněmovny Parlamentu České republiky konané ve dnech 25.10. - 26.10.2013. [online]. [citované 31. 7. 2020]. Dostupné na: https://volby.cz/pls/ps2013/ps.

ČESKÝ STATISTICKÝ ÚŘAD, 2017c: Volby do Poslanecké sněmovny Parlamentu České republiky konané ve dnech 20.10. - 21.10.2017 (promítnuto usnesení NSS). [on-line]. [citované 31. 7. 2020]. Dostupné na: https://volby.cz/pls/ps2017nss/ps?xjazyk=CZ

ČESKÝ STATISTICKÝ ÚŘAD, 2020: Výsledky voleb a referend. [on-line]. [citované 31. 5. 2020]. Dostupné na: https://volby.cz/

ČESKÝ STATISTICKÝ ÚŘAD, 2021: Veřejná databáze. [on-line]. [citované 31. 5. 2020]. Dostupné na: https://vdb.czso.cz/vdbvo2/

ESSLETZBICHLER, J. - DISSLBACHER, F. - MOSER, M., 2018: The Victims of Neoliberal Globalisation and the Rise of the Populist Vote: A Comparative Analysis of Three Recent Electoral Decisions. Cambridge Journal of Regions, Economy and Society, 11(1): 73-94. DOI: https://doi.org/10.1093/cjres/rsx025 
EVANS, G. - WHITEFIELD, S., 1995: Social and Ideological Cleavage Formation in Post-Communist Hungary. Europe-Asia Studies, 47: 11771204.

DOI: https://doi.org/10.1080/09668139508412314

EVANS, G. - WHITEFIELD, S., 1998: The Structuring of Political Cleavages in Post-Communist Societies: The Case of the Czech Republic and Slovakia. Political Studies 46(1): 115-139.

DOI: https://doi.org/10.1111/1467-9248.00133

EVANS, G. - WHITEFIELD, S., 2000: Explaining the Formation of Electoral Cleavages in Post-Communist Democracies. [on-line] [citované 17. 6. 2021]. Dostupné na: http://www.uh.edu/democracy/evansp.pdf

GREGOR, K., 2015: Who are Kotleba's Voters? Voters' Transitions in the Banská Bystrica Region in 2009 - 2014. Sociológia, 47(3): 235-252.

GREVE, M. - FRITSCH, M., - WYRWICH, M., 2021: Long-Term Decline of Regions and Rise of Populism: The Case of Germany. Jena Economic Research papers 2021-006. Jena: Friedrich-Schiller-University Jena. $32 \mathrm{~s}$.

HENDL, J., 2012: Přehled statistických metod. Analýza a metaanalýza dat. Praha: Portál. $736 \mathrm{~s}$.

HLOUŠEK, V. - KOPEČEK, L., 2004: Konfliktní demokracie. Moderní masová politika ve stř̌ední Evropě. Brno: Masarykova univerzita. $224 \mathrm{~s}$.

HOOGHE, L. - MARKS, G., 2017: Cleavage Theory Meets Europe's Crises: Lipset, Rokkan, and the Transnational Cleavage. Journal of European Public Policy 25(1): 109-135.

DOI: https://doi.org/10.1080/13501763.2017.1310279

IVARSFLATEN, E., 2008: What Unites Right-Wing Populists in Western Europe? Re-Examining Grievance Mobilization Models in Seven Successful Cases. Comparative Political Studies 41(1): 3-23.

DOI: https://doi.org/10.1177/0010414006294168

KALLIS, A., 2018: The Radical Right and Islamophobia. In: Rydgren, J. (ed.): The Oxford Handbook of the Radical Right. New York: Oxford University Press. s. 76-101.

KASPROWICZ, D., 2015: The Radical Right in Poland - from the Mainstream to the Margins. A Case of Interconnectivity. In: Minkenberg, M. (ed.): Transforming the Transformation? The East Euroopean Radical Right in the Political Process. Londýn: Routledge. s. 157-182.

KERN, A. - MARIEN, S. - HOOGHE, M., 2015: Economic Crisis and Levels of Political Participation in Europe (2002 - 2010): The Role of Resources and Grievances. West European Politics 38(3): 465-490.

DOI: https://doi.org/10.1080/01402382.2014.993152 
KITSCHELT, H., 1995: Formation of Party Cleavages in Postcommunist Democracies Theoretical Propositions. Party Politics 1(4): 447-472.

DOI: https://doi.org/10.1177/1354068895001004002

KLANDERMANS, B. - ROEFS, M. - OLIVIER, J., 2001: Grievance Formation in a Country in Transition: South Africa, 1994 - 1998. Social Psychology Quarterly 64(1): 41-54. DOI: https://doi.org/10.2307/3090149

KLANDERMANS, B. - VAN DER TOORN, J. - VAN STEKELENBBURG, J.. 2008: Embeddedness and Identity: How Immigrants Turn Grievances into Action. American Sociological Review 73(6): 992-1012. DOI: https://doi.org/10.1177/000312240807300606

KLUKNAVSKÁ, A. - SMOLÍK, J., 2016: We hate them all? Issue Adaptation of Extreme Right Parties in Slovakia 1993 - 2016. Communist and PostCommunist Studies 49(4): 335-344.

DOI: https://doi.org/10.1016/j.postcomstud.2016.09.002

KOSTELECKÝ, T. - ČERMÁK, D. 2002: Výběrová šetření a analýza agregátních dat - diskuse na téma použitelnosti různých př́stupů $\mathrm{v}$ komparativních analýzách politického chování. In: Kostelecký, T., Stachová, J., Čermák, D. (eds.): Region a politika. Praha: Sociologický ústav Akademie věd České republiky. s. 34-49.

KREKÓ, P. - MAYER, G., 2015: Transforming Hungary - Together? An Analysis of the Fidesz-Jobbik Relationship. In: Minkenberg, M. (ed.): Transforming the Transformation? The East Euroopean Radical Right in the Political Process. Londýn: Routledge. s. 183-205.

KUPKA, P. - LARYŠ, M. - SMOLÍK, J., 2009: Krajní pravice ve vybraných zemích střední a východní Evropy: Slovensko, Polsko, Ukrajina, Bělorusko, Rusko. Brno: Masarykova univerzita. $268 \mathrm{~s}$.

LIJPHART, A., 1999: Patterns of Democracy: Government Forms and Performances in Thirty-Six Countries. New Heaven and London: Yale University Press. $351 \mathrm{~s}$.

LIPSET, S. M. - ROKKAN, S., 1967: Cleavage Structures, Party Systems and Voter Alignments. In: Lipset, S. M., Rokkan, S. (eds.): Party Systems and Voter Alignments: Cross-National Perspectives. New York: Free Press. s. 164.

MADLEŇÁK, T., 2012: Regionálna diferenciácia volebného správania na Slovensku (1998-2010). Bratislava: Veda. $232 \mathrm{~s}$.

MAREŠ, M., 2003: Pravicový extremismus a radikalismus v ČR. Brno: Barrister a Principal. $655 \mathrm{~s}$.

MIKEŠOVÁ, R., 2019: Vliv lokálního prostředí na volební chování v Česku. Geografie, 124(4): 411-432.

DOI: https://doi.org/10.37040/geografie2019124040411 
MIKUŠ, R. - GURŇÁK, D., 2012: Vývoj pozícií politického extrémizmu, radikalizmu a nacionalizmu $\mathrm{v}$ rôznych úrovniach volieb na Slovensku. Geografické informácie, 16(2): 38-49.

MIKUŠ, R. - GURŇÁK, D., 2016: Rómska otázka ako jeden z mobilizačných faktorov volebnej podpory krajnej pravice na Slovensku a v Mad'arsku. Geographia Cassioviensis, 10(1): 29-46.

MIKUŠ, R. - GURŇÁK, D., 2019: Demokraticky k autokracii? Analýza volebnej podpory krajnej pravice na Slovensku, v Mad'arsku a Rumunsku. Bratislava: Univerzita Komenského. 200 s.

MINISTERSTVO PRÁCE A SOCIÁLNÍCH VĚCÍ, 2021: Nezaměstnanost měsíční. [on-line]. [citované 11. 5. 2021]. Dostupné na: https://www.mpsv.cz/web/cz/mesicni

MINKENBERG, M., 2002: The Radical Right in Postsocialist Central and Eastern Europe: Comparative Observations and Interpretations. East European Politics and Societies, 16(2): 335-362.

DOI: https://doi.org/10.1177/088832540201600201

MUDDE, C., 1996: The War of Words Defining the Extreme Right Party Family. West European Politics, 19(2): 225-248.

DOI: https://doi.org/10.1080/01402389608425132

MUDDE, C., 2000: Extreme-Rights Parties in Eastern Europe. Patterns of Prejudice, 34(1): 5-27. DOI: https://doi.org/10.1080/00313220008559132

MUDDE, C., 2005: Racist Extremism in Central and Eastern Europe. Londýn: Routledge. $308 \mathrm{s.}$

MUDDE, C., 2007: Populist Radical Right Parties in Europe, New York: Cambridge University Press. $385 \mathrm{~s}$.

PINK, M. - VODA, P., 2012: Vysvětlení prostorových vzorců volebního chovaní v parlamentních volbách v České republice a na Slovensku v letech 1996 - 2010. In: Pink, M., Eibl, O., Havlík, V., Madleňák, T., Spáč, P., Voda, P.: Volební mapy České a Slovenské republiky po roce 1993: vzorce, trendy, proměny. Brno: Centrum pro studium demokracie a kultury. s. 201242.

POLYAKOVA, A., 2015: The Backward East? Explaining Differences in Support for Radical Right Parties in Western and Eastern Europe. Journal of Comparative Politics, 8(1): 49-74.

PYTLAS, B., 2018: Radical Right Politics in East and West: Distinctive Yet Equivalent. Sociology Compass, 12(11): 1-15.

DOI: https://doi.org/10.1111/soc4.12632

RABUŠIC, L., 2004: Mnohonásobná lineární regrese. [on-line]. [cit: 17. 6. 2021]. Dostupné na: https://is.muni.cz/el/1423/podzim2004 /SOC418/mul tipl_regres_1.pdf 
ROSKIN, M., 1993: The Emerging Party Systems of Central and Eastern Europe. East European Quarterly 27(1): 47-63.

RYDGREN, J., 2007: The Sociology of the Radical Right. Annual Review of Sociology, 33: 241-262.

DOI: https://doi.org/10.1146/annurev.soc.33.040406.131752

SHUERMANS, N. - DE MAESSCHALCK, F., 2010: Fear of Crime as a Political Weapon: Explaining the Rise of Extreme Right Politics in the Flemish Countryside. Social \& Cultural Geography, 11(3): 247-262. DOI: https://doi.org/10.1080/14649361003637190

STANLEY, B., 2011: Populism, Nationalism, or National Populism? An Analysis of Slovak Voting Behaviour at the 2010 Parliamentary Election. Communist and Post-Communist Studies, 44(4): 257-270. DOI: https://doi.org/10.1016/j.postcomstud.2011.10.005

SUM, P., 2010: The Radical Right in Romania: Political Party Evolution and the Distancing of Romania from Europe. Communist and Post-Communist Studies, 43(1): 19-29.

DOI: https://doi.org/10.1016/j.postcomstud.2010.01.005

ŠTATISTICKÝ ÚRAD SR, 2010: Vol'by do Národnej rady Slovenskej republiky v roku 2010. Download výsledkov. [on-line]. [citované 11. 5. 2020]. Dostupné na: http://volby.statistics.sk/nrsr/nrsr2010/menu/indexd. jsp@lang=sk.htm.

ŠTATISTICKÝ ÚRAD SR, 2012: Vol'by do Národnej rady Slovenskej republiky v roku 2012. Download výsledkov. [on-line]. [citované 11. 5. 2020]. Dostupné na: http://volby.statistics.sk/nrsr/nrsr2012/menu/indexd. jsp@lang=sk.htm.

ŠTATISTICKÝ ÚRAD SR, 2016: Vol'by do Národnej rady Slovenskej republiky v roku 2016. Súbory na stiahnutie. [on-line]. [citované 11. 5. 2020].

Dostupné

na: http://volby.statistics.sk/nrsr/nrsr2016/sk/download.html.

ŠTATISTICKÝ ÚRAD SR, 2020: Vol'by do Národnej rady Slovenskej republiky v roku 2020. Súbory na stiahnutie. [on-line]. [citované 11. 5. 2020]. Dostupné na: https://volby.statistics.sk/nrsr/nrsr2020/sk/download .html

ŠTATISTICKÝ ÚRAD SR, 2021a: Verejná databáza DATAcube. [on-line]. [citované 11. 5. 2021]. Dostupné na: http://datacube.statistics.sk/

ŠTATISTICKÝ ÚRAD SR, 2021b: Vol'by a referendá. [on-line]. [citované 11. 5. 2021]. Dostupné na: https://volby.statistics.sk/

ÚSTREDIE PRÁCE, SOCIÁLNYCH VECÍ A RODINY 2021: Nezamestnanost' - mesačné štatistiky. [on-line]. [citované 11. 5. 2021]. Dostupné na: https://www.up svr.gov.sk/statistiky/nezamestnanost-mesacne-statistiky. html?page_id=1254 
VAN GENT, W. P. C. - JANSEN, E. F. - SMITS, J. H. F., 2014: Right-wing Radical Populism in City and Suburbs: An Electoral Geography of the Partij Voor de Vrijheid in the Netherlands. Urban Studies, 51(9): 1775-1794.

DOI: https://doi.org/10.1177/0042098013505889

VASILOPOULOU, S., 2018: The Radical Right and Euroskepticism. In: Rydgren J. (ed.): The Oxford Handbook of the Radical Right. New York: Oxford University Press. s. 189-212. 